Hussin Alam

ORCID: 0000-0002-0652-3334

Uniwersytet Wrocławski

Agnieszka Makarewicz-Marcinkiewicz

ORCID: 0000-0002-0501-4810

Uniwersytet Wrocławski

\title{
Rola biznesu społecznego w procesie upodmiotowienia kobiet w Bangladeszu na przykładzie działalności organizacji BRAC w dystrykcie Magura
}

DOI: 10.19195/1643-0328.25.5

Słowa kluczowe: upodmiotowienie kobiet, biznes społeczny (Social Business), BRAC (Bangladesh Rehabilitation Assistance Committee)

\section{Wprowadzenie}

Biznes społeczny to forma działalności gospodarczej. Zaangażowani w nią inwestorzy (właściciele) mogą stopniowo odzyskiwać zainwestowane pieniądze, nie mogą jednak liczyć na dywidendy. Wyłącznym celem inwestycji jest bowiem realizacja dążeń społecznych. Inwestorzy nie odnoszą przy tym żadnych korzyści osobistych. Firma rozpoczynająca działalność w ramach takiego projektu musi pokryć wszystkie koszty i osiągnąć zysk, realizując jednocześnie cel społeczny - może nim być np. opieka zdrowotna, mieszkania czy usługi finansowe dla ubogich, dożywianie dzieci, zapewnianie dostępu do wody pitnej, wprowadzanie odnawialnych źródeł energii itp.

Upodmiotowienie polega na stopniowym wzroście duchowej, politycznej, społecznej i ekonomicznej siły jednostek, społeczności lub całych społeczeństw. Wzmocnienie pozycji społecznej często pociąga za sobą wzrost wiary we własne możliwości. Upodmiotowienie kobiet jest wielowymiarowym procesem, dzięki któremu mogą one stać się podmiotami instytucji publicznych ${ }^{1}$. Wzmocnienie pozycji kobiet wiąże się również z ich pełnym

${ }^{1}$ H. Sholkamy, How can social protection provide social justice for women?, „Pathways Policy Paper” październik 2011; eadem, Steady Money. State Support and Respect Can Equal Woman's Empowerment 
udziałem w życiu gospodarczym we wszystkich sektorach, co jest bardzo istotne w kontekście wzmocnienia gospodarek i osiągnięcia pożądanych celów zrównoważonego rozwoju ${ }^{2}$.

W niniejszym artykule przedstawiono proces upodmiotowienia ubogich kobiet z obszarów wiejskich dystryktu Magura w Bangladeszu, który został zainicjowany przez organizację BRAC. Hipoteza pracy odnosi się do efektywności działań z zakresu biznesu społecznego: biznes społeczny przyczynia się do zmiany świadomości praw i własnej wartości kobiet biorących udział w projektach oraz do poprawy ich statusu społeczno-ekonomicznego.

Weryfikacji hipotezy, oprócz przeglądu literatury, posłużą wyniki badania własnego o charakterze jakościowym, przeprowadzonego w roku 2016 w Magurze (zastosowane techniki badawcze zaprezentowane zostały w dalszej części artykułu). Celem badania było udzielenie odpowiedzi na następujące pytania:

1. W jaki sposób organizacja BRAC nauczyła kobiety z Magury w Bangladeszu zasad biznesu społecznego?

2. W jaki sposób nauka zasad biznesu społecznego i ich realizacja umocniły pozycję kobiet z Magury i rozpoczęły proces ich upodmiotawiania?

3. Jakie wyzwania stanęły przed BRAC w nauczaniu zasad biznesu społecznego oraz prowadzenia własnej działalności gospodarczej kobiet z Magury?

\section{Biznes społeczny w procesie upodmiotawiania kobiet}

Według twórcy koncepcji biznesu społecznego (Social Business), Muhammada Yunusa, polega on na całkowitym poświęceniu finansowej korzyści dla celów społecznych i wiąże się z odcięciem się od poprzedniej struktury biznesowej. Nie chodzi tu o uwzględnienie nowych celów w istniejących już od dawna ramach prowadzenia działalności gospodarczej. Zdaniem autora, jeśli nie dojdzie do oddzielenia działalności od osobistych korzyści finansowych, nie uda się wdrożyć prawdziwego biznesu społecznego. Zdarzają się przypadki działalności w ramach biznesu społecznego teoretycznie prowadzonych według ustalonych standardów, których inicjatorzy nastawieni są jednak na osiągnięcie zysku za pośrednictwem innych firm, np. poprzez sprzedaż produktu lub usługi firmie z branży społecznej. Jest to wyraźny sabotaż pierwotnej idei. Istnieje wiele innych subtelnych sposobów, dzięki którym można osłabić koncepcję i praktykę biznesu społecznego. Prawdziwy przedsiębiorca społeczny musi dołożyć wszelkich starań, aby nie wpaść w tę pułapkę, także nieświadomie ${ }^{3}$.

Muhammad Yunus zdemaskował kapitalizm jako system, który stworzył ubóstwo, koncentrując się wyłącznie na zyskach. W ramach systemu ekonomicznego zbudowano bajkę pomyślności dla wszystkich, która się nigdy nie ziściła. Dlatego państwa europej-

in Egypt, [w:] Feminisms, Empowerment and Development: Changing Women's Lives, red. A. Cornwall, J. Edwards, London 2014.

2 E. Duflo, Women empowerment and economic development, „Journal of Economic Literature” 50 (4), 2012, s. 1051-1079.

${ }^{3}$ M. Yunus, Social business, http://www.muhammadyunus.org/index.php/social-business/socialbusiness (dostęp: 1.05.2018). 
skie zdecydowały się powierzyć swym rządom kwestie ubóstwa, bezrobocia i ochrony zdrowia. Jak zauważa autor, „byli na tyle sprytni, aby odkryć pustkę kapitalizmu w rozwiązywaniu tych problemów"'.

Biznes społeczny wprowadza do gospodarki wolnorynkowej całkowicie nowy, rewolucyjny wymiar. Nie koliduje to z mechanizmem generowania zysków, przeciwnie — sprzyja inwestycjom, zarządzaniu i konkurencyjności, przy czym inwestorzy nie otrzymują tutaj żadnej dywidendy, choć mogą odzyskać zainwestowane środki, jeśli zechcą reinwestować je w inne firmy społeczne. Satysfakcja uzyskana w osiąganiu określonych celów społecznych jest jedynym motywem inwestycji, a powstały biznes jest oceniany zgodnie z tym standardem. Funkcjonują dwa typy biznesu społecznego. Typ pierwszy koncentruje się na przedsiębiorstwach zajmujących się jedynie celami społecznymi, np. wytworzony w takim przedsiębiorstwie produkt jest przeznaczony dla osób ubogich. W drugim przypadku można zająć się każdą zyskowną działalnością pod warunkiem, że będzie ona własnością osób ubogich, które z tej działalności odniosą bezpośrednie korzyści ${ }^{5}$.

Biznes społeczny to idea, która zrzesza przedsiębiorców wierzących w możliwość stworzenia świata bez ubóstwa. Jest to rodzaj inwestycji kapitałowej, która służy ubogim poprzez zaspokajanie ich potrzeb. Oscyluje wokół dwóch głównych aspektów natury ludzkiej: egoizmu i bezinteresowności ${ }^{6}$. Ponieważ ludzie różnią się między sobą, ów czynnik ludzki również będzie zależał od konkretnej osoby. Social Business można nazwać konglomeracją bezinteresownych instytucji, które nie mają na celu przekształcenia prostych ludzi w potentatów biznesu?

Upodmiotowienie kobiet jest drażliwym tematem w społeczeństwach państw rozwijających się. Upodmiotowienie można zdefiniować jako całkowitą duchową, polityczną i ekonomiczną siłę kobiet. Sohela Nazneen i Syeda Tasneem wykazały, że kiedy kobiety zostały upodmiotowione, głównie przez edukację i pracę zarobkową, przejęły kontrolę nad swymi działaniami i zaczęły się cieszyć prawem do podejmowania decyzji zarówno w rodzinie, jak i w społeczeństwie. Obecnie w społeczeństwach rozwijających się dąży się do tego, aby każda kobieta otrzymała co najmniej podstawowe wykształcenie ${ }^{8}$. Władze, ale przede wszystkim organizacje pozarządowe, uzasadniają konieczność edukacji kobiet przynajmniej na poziomie podstawowym tym, by w przyszłości nikt ich nie oszukiwał, a do takich sytuacji dochodzi obecnie nagminnie, nawet $w$ ich domach rodzinnych. Zapewnienie kobietom wykształcenia jest podstawowym narzędziem upodmiotowienia, zwłaszcza w sytuacji, kiedy brakuje innych środków 9 .

Ażeby proces upodmiotowienia kobiet był kontynuowany, należy umożliwić im zdobywanie wykształcenia. Edukacja kobiet jest podstawą wzmocnienia ich pozycji. Dopóki

${ }^{4}$ Ibidem.

5 Ibidem.

6 M.M. Esther, Empowerment for grassroots women, „Development” 53 (2), 2010, s. 197-199.

7 P. Johnson, Unmarried in Palestine: Embodiment and disempowerment in the lives of single Palestine women, „IDS Bulletin” 41 (2), 2010, s. 106-115.

8 S. Nazneen, S. Tasneem, A silver lining: Women in reserved seats in local government in Bangladesh, „IDS Bulletin” 41 (5), 2010, s. 35-42.

9 M.M. Esther, op. cit., s. 198. 
kobiety nie uzyskają prawa do edukacji, ani polepszenie ich statusu, ani rozwój społeczno-gospodarczy całego kraju nie będą możliwe. Kobiety stanowią prawie $50 \%$ całej populacji Bangladeszu. Nie można osiągnąć pożądanych celów rozwojowych, ignorując połowę populacji ${ }^{10}$.

Swoiste uwłasnowolnienie stanowi ogromną siłę wspólnoty kobiet w każdym społeczeństwie i jest niezbędne do ustanawiania nowych praw. Koncepcja wzmocnienia pozycji kobiet obejmuje zrozumienie etosu samowystarczalności, prawa do wyboru, prawa do podejmowania decyzji, prawa do implementacji powziętej decyzji w oparciu o okoliczności oraz zdolność wpływania na inne kobiety w społeczeństwie, a w rezultacie także wpływ na rozwój społeczno-gospodarczy całego społeczeństwa ${ }^{11}$.

Wzrost wrażliwości na kwestie płci jest jednym z najważniejszych problemów ostatnich czasów. Kobiety - matki narodu powinny być silne i świadome. Dążenie do świadomości, a dzięki niej do samodzielności, należy do głównych motorów upodmiotawiania kobiet przez kobiety ${ }^{12}$. UNDP (United Nations Development Programme - Program Narodów Zjednoczonych ds. Rozwoju) skupia się współcześnie w dużej mierze na równości płci i umocnieniu pozycji kobiet, nie tylko jako na podstawowych prawach człowieka. Organizacja postrzega kobiety także jako podmioty, których zaangażowanie jest niezbędne do osiągnięcia milenijnych celów rozwoju, włączając w to rozwój zrównoważony. Dlatego też UNDP ukierunkowuje swe działania na zmniejszenie dyskryminacji ze względu na płeć: koordynuje globalne i krajowe wysiłki mające na celu połączenie równouprawnienia płci i wzmocnienia pozycji kobiet w ramach różnych programów redukcji ubóstwa, promuje demokratyczne zarządzanie oraz zapobieganie kryzysom, a także zrównoważony rozwój środowiska przy zachowanym wzroście gospodarczym ${ }^{13}$.

Poprzez swoją globalną sieć UNDP pracuje nad tym, aby kobiety miały swoją reprezentację we wszystkich typach instytucji zarządzających, od poziomu sądownictwa po służby cywilne, od sektora prywatnego po instytucje społeczeństwa obywatelskiego. Celem organizacji jest zagwarantowanie równego uczestnictwa kobiet w życiu publicznym i procesie decyzyjnym w sposób, który pozwoli im skutecznie wpływać na decyzje determinujące przyszłość ich rodzin, a także krajów ${ }^{14}$.

W okresie wedyjskim w Azji Południowej kobiety miały równe z mężczyznami prawa, stopniowo jednak sytuacja ta ulegała zmianie na niekorzyść kobiet. Aby poprawić sytuację, niektóre organizacje pozarządowe podjęły się próby pomocy ubogim kobietom $\mathrm{w}$ procesie odzyskiwania ich praw. Czynią to przede wszystkim poprzez zapewnienie kobietom edukacji, tak aby dzięki obudzonej świadomości i zdobytej wiedzy podjęły one walkę z wymierzoną w nie niesprawiedliwością społeczną.

10 P. Johnson, op. cit.

11 M. Tadros, Woman in Politics: Gender, Power and Development, London 2014.

12 M. Yunus, K. Weber, Building Social Business, New York 2010.

13 A. Cornwall, Women empowerment: What works and why?, „World Institute for Development Economics Research" 4 (3), 2014, s. 1-30.

14 P. Debdatta, O. Dutta, Microcredit and empowerment of urban women: A study from Eastern India, „Strat Change” 24 (2), 2015, s. 149-163. 


\section{Działalność międzynarodowej organizacji pozarządowej BRAC}

Edukacja, jaką otrzymują kobiety w Bangladeszu od organizacji pozarządowych, zwłaszcza tych zaangażowanych w promowanie idei społecznego biznesu, wspiera nie tylko połowę populacji tego kraju, ale także sprzyja rozwojowi społeczno-gospodarczemu i podnosi jakość życia dzieci. Przekonuje się, że jeśli kobiety odważą się zgłosić i dołączyć do którejkolwiek organizacji pozarządowej, by uczyć się i zdobywać wykształcenie, decyzja ta przyczyni się do poprawy kondycji finansowej całej rodziny oraz, co najważniejsze, że poprzez prowadzenie własnej działalności gospodarczej staną się niezależne. Wskazuje się, iż to właśnie organizacje pozarządowe zawsze były agentami zmian w odniesieniu do sytuacji kobiet w Bangladeszu ${ }^{15}$.

Przedsiębiorstwa, które powstają pod auspicjami biznesu społecznego, są zawiadywane głównie przez organizacje pozarządowe. Organizacje te skupiają się w swej działalności inwestycyjnej na konkretnym problemie - rozpracowują go, inwestują w badania, a następnie wdrażają rozwiązania. Są to przedsiębiorstwa samofinansujące się, które działają na rzecz ludzi z różnych społeczności, zwłaszcza na rzecz ubogich i potrzebujących, co ważne: bez szacowania zysków ze swej działalności. Niezależnie bowiem od tego, jaki zysk osiągnie przedsiębiorstwo, inwestuje ono dalej w poprawę swojej działalności. Ten rodzaj działalności społecznej jest w dużym stopniu uzależniony od darowizn i środków przekazywanych organizacjom pozarządowym przez różne organizacje i firmy, które są zainteresowane pomocą ubogim, zmianą warunków życia w społeczeństwie oraz wzmocnieniem potencjału państwa poprzez edukację ${ }^{16}$.

BRAC (Bangladesh Rehabilitation Assistance Committee) jest jedną z niewielu międzynarodowych organizacji pozarządowych działających w krajach globalnego Południa. Założona została w Bangladeszu w 1972 r. przez Fazlé Hasana Abeda w Shallah Upazillah w okręgu Sunamganj jako projekt przeprowadzany na niewielką skalę, na rzecz pomocy (w tym rehabilitacji) powracającym z wojny wyzwoleńczej w Bangladeszu. BRAC obecnie działa $z$ dużym powodzeniem w 11 krajach. Organizacja oferuje programy z zakresu mikrofinansów, edukacji, opieki zdrowotnej, uświadamiania i realizacji praw, wzmocnienia pozycji kobiet i dziewcząt, rolnictwa oraz społecznie odpowiedzialnych przedsiębiorstw. Ponadto prowadzi bank, uniwersytet i jedną z największych na świecie mobilnych platform pieniężnych - bKash.

Roczne wydatki globalne BRAC przekraczają 1 miliard USD. Organizacja jest również wyjątkowa $z$ tego względu, że większość jej programów jest samofinansująca się. $\mathrm{W}$ Bangladeszu ponad 75\% budżetu organizacji pochodzi $\mathrm{z}$ własnych przedsiębiorstw społecznych, które obejmują projekt mleczarski i żywnościowy oraz sieć detalicznych sklepów z wyrobami rękodzielniczymi. Ów innowacyjny model zwrotu kosztów jest często doceniany, co ma swój wyraz w międzynarodowych rankingach NGO. BRAC zatrudnia ponad 100000 osób, z których ok. 70\% to kobiety. Dzięki swoim usługom

15 M. Sagot, Does the political participation of women matter? Democratic representation, affirmative action and quotas in Costa Rica, „IDS Bulletin” 41 (5), 2010, s. 25-34.

16 S. Khattak, Women in local government: The Pakistan experience, „IDS Bulletin” 41 (5), 2010, s. 52-61. 
dociera do ponad 126 mln osób. Organizacja wdraża swoje programy, specjalizując się w rozwiązywaniu sytuacji konfliktowych oraz w interwencjach po katastrofach. Co więcej, wskazuje się, że BRAC wprowadza holistyczną wizję pomocy, której celem ostatecznym jest osiągnięcie zrównoważonego rozwoju całego społeczeństwa. W 2018 r. BRAC została uznana za najlepszą organizację pozarządową na świecie $w$ rankingu opracowanym przez NGO Advisor, niezależną organizację medialną z siedzibą w Genewie, oraz trzeci rok z rzędu zajęła pierwsze miejsce $\mathrm{w}$ rankingu Top 500 organizacji pozarządowych ${ }^{17}$.

W ramach programu mikrofinansowego BRAC wykorzystywane są coraz to nowsze sposoby, aby poprawić jego efektywność. Grupa decyzyjna zazwyczaj składa się z 30-40 osób, konstytuujących tzw. organizacje wiejskie (Village Organisations, VO). Organizacja wiejska jest wydajnym mechanizmem operacyjnym służącym do uruchamiania i wdrażania różnych zadań. Aby VO były bardziej efektywne, ich członkowie są podzieleni na mniejsze grupy, które zwykle liczą 5-7 członków. Pracownicy BRAC spotykają się z członkami VO raz w tygodniu, odnosząc się do następujących kwestii: świadome podejmowanie decyzji, prawa i obowiązki kredytobiorców, prowadzenie ewidencji, zapobieganie nadmiernemu zadłużeniu, wsparcie w nagłych wstrząsach i sytuacjach kryzysowych, załatwianie skarg i rozwiązywanie problemów, działalność generująca dochód ${ }^{18}$.

BRAC odegrała wielką rolę w procesie upodmiotowienia kobiet na obszarach wiejskich w Bangladeszu. Pierwszym etapem implementacji projektu jest przeprowadzenie badań mających na celu poznanie społeczności kobiet wiejskich, ich potrzeb i deficytów edukacyjnych, a następnie dostosowanie do nich programów szkoleń i kształcenia. Ocenia się, że organizacje pozarządowe były jedyną szansą dla ubogich bangladeskich kobiet na kształcenie, które, jak się okazało, zmieniło całe ich życie ${ }^{19}$. W rzeczywistości kobiety w Magurze potrzebowały edukacji, by przetrwać.

\section{Wyniki badania procesu upodmiotowienia z udziałem BRAC na obszarach wiejskich dystryktu Magura}

Magura to dystrykt i miasto w południowo-zachodniej części Bangladeszu. Dystrykt zajmuje powierzchnię $1048 \mathrm{~km}^{2}$, a całkowita populacja wynosi 918419 osób (w tym 454739 mężczyzn i 463680 kobiet ${ }^{20}$. Badania własne dotyczące procesu upodmiotowienia kobiet

17 BRAC ranked top global NGO of 2018, http://www.brac.net/latest-news/item/1145-brac-ranked-topglobal-ngo-of-2018 (dostęp: 1.05.2018).

18 Y. Chen, Microfinance program in BRAC - the largest NGO in the world, IEPM 3110, International Organizations and Economic Development, s. 11, https://staticl.squarespace.com/static/56645cece4b09 57c43a61e07/t/5696623ad8af10829fdfb431/1452696125594/3110+term+paper_final.pdf(dostęp: 1.05.2018).

19 C. Sardenberg, What makes domestic violence legislation more effective?, „Pathways Policy Paper” październik 2011.

20 Magura District Information, http://aboutbangladesh71.blogspot.com/2013/01/magura-districtbangladesh.html (dostęp: 1.05.2018). 
z udziałem BRAC na obszarach wiejskich tego dystryktu miały charakter jakościowy i przeprowadzone zostały w okresie od lutego do czerwca $2016 \mathrm{r}$.

Wykorzystano technikę ustrukturyzowanego wywiadu pogłębionego oraz analizę treści dokumentów urzędowych dotyczących bieżącej sytuacji życiowej kobiet z obszarów wiejskich dystryktu Magura (stanu zdrowia, dzietności, udziału w rynku pracy). Badanie dotyczyło przede wszystkim tego, w jaki rodzaj działalności gospodarczej kobiety objęte projektem były zaangażowane, jakie obowiązki rodzinne jednocześnie wykonywały, jak wyglądała ich sytuacja finansowa i rodzinna oraz tego, jaką aktywnością wykazywały się ich dzieci. W przypadku wywiadów pogłębionych wśród respondentów znalazło się osiem kobiet $\mathrm{z}$ obszarów wiejskich Magury oraz trzech menedżerów. Menedżerowie brali udział w nauczaniu biznesu społecznego, a także zapewnili kapitał na rozpoczęcie społecznej działalności gospodarczej. Dane zostały zakodowane i podzielone na kategorie na podstawie podobieństwa i odmienności. Wywiady przeprowadzone zostały w języku bengalskim i w pierwszej kolejności przetłumaczone na język angielski.

Pierwsze wnioski pojawiły się już podczas kodowania i kategoryzacji danych. Analizie poddane zostały następujące kategorie wynikające $\mathrm{z}$ planu badawczego lub będące pokłosiem projektu, które wpłynęły bezpośrednio na życie kobiet w Magurze: szkolenia i motywacja; zdolność finansowa i wkład w rodzinę; wyzwania społeczne związane z płcią i religią; budowanie poczucia własnej wartości w kobietach.

\section{Szkolenia i motywacja}

Głównym celem współpracy BRAC z ubogimi kobietami było uświadomienie im ich praw, przez to także poprawa ich statusu $\mathrm{w}$ rodzinie i społeczeństwie, a w szerszym aspekcie - przyczynienie się do realizacji koncepcji rozwoju zrównoważonego, której implementacja nie jest możliwa bez udziału całej, na równi upodmiotowionej populacji. Jednym z podstawowych programów realizowanych przez BRAC jest Program Wspierania Społeczności ukierunkowany właśnie na ustanowienie praw kobiet i wzmocnienie ich pozycji. BRAC rozpoczęła pracę z kobietami w Magurze od podniesienia świadomości z zakresu różnych negatywnych i pozytywnych aspektów życia społecznego w Bangladeszu, co miało poskutkować zmianą percepcji tych zjawisk. Omawiano proceder nakłaniania do zawierania małżeństw przez bardzo młode kobiety poniżej osiemnastego roku życia, tradycyjny obowiązek wniesienia posagu, kwestię rozwodów, gwałtów, ataków kwasem, ale także planowania rodziny czy immunizacji. W trakcie spotkań/szkoleń wielokrotnie podkreślano wagę aktywnego udziału kobiet w lokalnej strukturze władzy wioski oraz we wszelkich procesach decyzyjnych, a także sprawiedliwy podział zasobów i równe wynagrodzenie dla mężczyzn i kobiet.

Kampanie edukacyjne organizowane były w różnych częściach Magury. Na początku projektu były to przede wszystkim spotkania w większym gronie kobiet, a następnie, po pozyskaniu zaufania kobiet i zgody ich rodzin, menedżerowie z BRAC udawali się do domów kobiet chcących zaangażować się w biznes społeczny. Warto wspomnieć, że 
początkowo organizacja współpracowała $z$ większą liczbą kobiet niż ta, której następnie mogła zaproponować finansowanie. BRAC zdecydowała się na takie rozwiązanie, aby w większym gronie, bardziej rzetelnie i trafnie przedyskutować problemy kobiet, a sam projekt zyskał w ten sposób na reprezentatywności.

Wolontariusze BRAC odwiedzili osiem biednych, pogrążonych w analfabetyzmie domów, by w naturalnym środowisku kobiet zidentyfikować główne problemy, z którymi się wówczas borykały. Co znamienne, jeden z trzech menedżerów w projekcie stwierdził, że kobiety z Magury nie postrzegały swego życia jako problematycznego. Wszystko, co je w życiu spotykało (łącznie z katorżniczą pracą, wykorzystywaniem seksualnym czy karami cielesnymi), przyjmowały jako normę społeczną. Kobiety te uważały, że życie, które prowadziły, było normalne, ponieważ tak samo żyły inne kobiety z ich otoczenia. Menedżerowie zrzeszeni w BRAC musieli się ciężko napracować, aby kobiety zrozumiały, że ich życie jest równie cenne jak życie mężczyzn i że nie muszą cierpieć biedy, mogą natomiast zmienić swą sytuację, gdy tylko zechcą.

Przedsiębiorcy i zarazem wolontariusze BRAC przeprowadzali po trzy-cztery treningi w tygodniu, w czasie których uczestniczki zapoznawały się ze strategiami i nabywały umiejętności umożliwiające im walkę o ich prawa. Pierwsze szkolenie dotyczyło tego, jak przekonać rodzinę, aby pozwoliła im przyjść na następne. Trenerzy dawali wskazówki, jak być silniejszą psychicznie i fizycznie, jak odważnie stawić czoła każdej niekorzystnej sytuacji, jakie prawa przysługują kobietom i jak mogą uzyskać pomoc prawną od rządu, jeśli ktoś dopuści się wobec nich niesprawiedliwości. Co ważne, jeden z menedżerów BRAC specjalizujący się w finansach stwierdził, przeprowadziwszy swoje warsztaty, że jeśli tylko więcej kobiet będzie miało szansę wzięcia udziału w tego typu projektach, to społeczeństwo będzie świadkiem wysokiego i stałego wzrostu gospodarki w Bangladeszu.

\section{Zdolność finansowa i wkład w rodzinę}

W wyniku szkoleń i dyskusji na cotygodniowych spotkaniach osiem kobiet biorących udział w projekcie nabrało świadomości swoich praw w rodzinie i społeczeństwie. Uczestniczki projektu stały się silniejsze mentalnie i zaczęły brać udział w podejmowaniu decyzji dotyczących ich rodzin. O zapoczątkowaniu procesu upodmiotawiania tych kobiet najlepiej świadczy opinia jednej z uczestniczek wywiadów pogłębionych:

Teraz mój mąż mówi mi, jeśli czegoś chce, lub przynajmniej informuje o swoich zamiarach. Wcześniej nie wiedziałam, jakie ma plany, co zrobi i ze strachu nie pytałam go o nic. Teraz wysyłam moją córkę do szkoły, chociaż mój mąż nie popiera edukacji kobiet. Ja jednak już wiem, jak ważna jest edukacja.

Po treningu z BRAC osiem kobiet doszło do wniosku, że nie urodziły się tylko po to, by rodzić dzieci, opiekować się rodziną męża i wykonywać domowe obowiązki. Zaczęły być znacznie bardziej otwarte i pracować na polach razem ze swoimi mężami lub czasami samotnie, by uniknąć społecznych i religijnych szykan. Jedna z tych silnych kobiet stwierdziła podczas wywiadu: 
Moje życie było dotąd piekłem. Gdy zaczęłam marzyć o lepszej przyszłości, moje życie zostało zmarnowane błędnymi decyzjami mojej niepiśmiennej, ubogiej rodziny. Wyszłam za mąż, będąc pod presją rodziny, kiedy miałam czternaście lat. Po ślubie zrozumiałam, że nikt z rodziny mojego męża mnie nie akceptuje i nie chciałam pracować dla nich dzień i noc. Kiedy BRAC pojawił się w naszej okolicy i zaoferował mi możliwość nauki biznesu społecznego, skorzystałam z tej oferty bez pozwolenia mojego męża, chociaż było to dla mnie bardzo ryzykowne, ponieważ mój mąż bił mnie, gdy robiłam cokolwiek bez jego zgody. BRAC poprzez szkolenia oraz wsparcie finansowe wyposażył mnie w wiedzę i możliwości, dzięki którym mogę prowadzić własny interes i zarabiać.

Uczestniczka projektu, o której mowa, za otrzymane pieniądze kupiła cztery krowy, otworzyła mały sklep spożywczy, wychowując w tym samym czasie dwoje dzieci. Kobieta stwierdziła, że jej życie bardzo się zmieniło dzięki zyskom ze sklepu i sprzedaży mleka. Te osiem ubogich kobiet stało się wzorami dla innych kobiet w Magurze, które także zaczęły dążyć do swego upodmiotowienia i zakładać własną działalność społeczną. $\mathrm{W}$ trakcie szkoleń prowadzonych przez BRAC wiele ubogich kobiet z Magury pozyskało wiedzę na temat usług społecznych, psychologii społecznej, zdrowia publicznego i rozwoju społeczności. W literaturze przedmiotu często pojawia się stwierdzenie, że wzmocnienie pozycji kobiet i rozwój gospodarczy są z sobą ściśle powiązane ${ }^{21}$. Gdy kobiety w Magurze zaczęły generować dochody, ich głos zaczął być honorowany zarówno w rodzinie, jak i w społeczeństwie, co świadczy o ich upodmiotowieniu.

\section{Wyzwania społeczne związane z płcią i religią}

Mimo że od historycznej konferencji na temat praw kobiet w Pekinie w roku 1995 minęło ponad 20 lat, to nadal w ponad 170 krajach na świecie istnieją bariery prawne, które uniemożliwiają kobietom korzystanie z tych samych praw, zabezpieczeń i swobód, którymi cieszą się mężczyźni. Osiem kobiet biorących udział w projekcie BRAC potwierdziło, że musiały stawić czoła wielu barierom religijnym, społeczno-kulturowym oraz genderowym, aby móc rozpocząć działalność z zakresu biznesu społecznego. Jedna z kobiet powiedziała, że urodziła się w biednej rodzinie i wyszła za człowieka należącego do konserwatywnej rodziny muzułmańskiej, w której zasady funkcjonowania kobiety sprowadzały się do gotowania, sprzątania, rodzenia i opieki nad dziećmi. Konserwatywna rodzina nie tolerowała kobiet, które zajmowały się działalnością społeczną, pracą lub zwyczajnie opuszczały domostwo.

Dwie uczestniczki projektu przyznały, że były dyskryminowane w swych miejscach pracy jedynie z powodu bycia kobietami. Wykonywały tę samą pracę, jednak pod koniec dnia mężczyźni otrzymywali znacznie wyższe wynagrodzenie. Do tej pory w niektórych częściach Bangladeszu wszelka działalność kobiet jest tłumiona na wiele sposobów. Ten stan rzeczy potwierdzają badania. Zaobserwowano, że pomimo wprowadzenia prawa dotyczącego kobiet, w dużej mierze są one nadal wykorzystywane w społeczeństwie,

21 T. Lewin, Communicating empowerment: Countering the cardboard women, „Development” 53 (2), 2010, s. 222-226. 
a normy religijne i społeczne stanowią jedne z najpoważniejszych barier, z którymi większość kobiet wciąż się boryka i które zdecydowanie spowalniają proces wzmacniania pozycji kobiet w Bangladeszu ${ }^{22}$.

\section{Budowanie poczucia własnej wartości w kobietach}

W fazie przygotowawczej do przeprowadzenia projektu osiem uczestniczek zostało kompleksowo przebadanych przez lekarza. Okazało się, że wszystkie były niedożywione. Jednak ich siła psychiczna była ogromna, prawdopodobnie dlatego, że musiały dużo wycierpieć z powodu nadmiernej, wręcz wyniszczającej pracy, braku wystarczającej ilości jedzenia i tortur ze strony mężów i rodziny. Kiedy skorzystały $z$ oferty BRAC i przeszły szkolenia, ich poziom pewności siebie wzrósł i stały się znacznie odważniejsze niż wcześniej. Dzięki pracy z wolontariuszami BRAC mogły zrozumieć swoje rzeczywiste problemy i nauczyć się, jak je stopniowo rozwiązywać. Wszystkie osiem kobiet zebrało się na odwagę, by przełamać wszelkie bariery o podłożu rodzinnym i społecznym. Udało im się wyzwolić od dyskryminacji religijnej i społecznej. BRAC nauczyła je, jak ustanowić swoje prawa na nowo zarówno w rodzinie, jak i w społeczeństwie. Odwaga i odporność tych ośmiu kobiet pomogły wielu innym wyjść ze stanu ubezwłasnowolnienia, który dotąd stanowił normę w Bangladeszu. Wszystkie kobiety twierdziły, że po nauczeniu się funkcjonowania w biznesie społecznym zaczęły się cieszyć niespotykanym dotychczas szacunkiem w ich społeczności. Mogły poczynić inwestycje w edukację i inne potrzeby rozwojowe swoich dzieci. Rozpoczęcie działalności gospodarczej w ostatecznym rozrachunku umocniło nie tylko pozycję kobiet, ale także, przynajmniej częściowo, upodmiotowiło dzieci. Aktywizacja kobiet pozwoliła na obserwację, iż są one doskonałymi menedżerami ryzyka i skutecznie zawiadują sytuacjami kryzysowymi.

\section{Podsumowanie}

W toku badań wykazano, że zainicjowana przez organizację BRAC działalność z zakresu biznesu społecznego przyczyniła się do wzmocnienia pozycji praktycznie ubezwłasnowolnionych dotąd kobiet w dystrykcie Magura w Bangladeszu. BRAC nie tylko szkoliła zrzeszeni w niej przedsiębiorcy przekazali kobietom kapitał na rozpoczęcie działalności.

Organizacja nauczyła je, jak prowadzić biznes społeczny, w jaki sposób osiągać zyski, jak mierzyć się z trudnościami. Tradycja rodzinna i lokalna, przesądy, zwyczaje społeczne stanowiły poważne przeszkody w upodmiotawianiu kobiet, jednak, jak pokazuje przykład kobiet z Magury, nie były to bariery nie do pokonania. Biznes społeczny okazał się skutecznym narzędziem normalizowania społeczno-ekonomicznej pozycji kobiet w Magurze, co pozwala sądzić, że podobne inicjatywy będą powielane $z$ sukcesem w innych

22 P. Debdatta, O. Dutta, op. cit., s. 154. 
częściach kraju. Doświadczenia pracowników BRAC mogą również zostać wykorzystane przez inne osoby działające w obszarze upodmiotowienia kobiet.

Znamienne są obserwacje jednego $\mathrm{z}$ menedżerów biorących udział w projekcie, na którym ogromne wrażenie zrobiły możliwości percepcyjne szkolonych kobiet. Stwierdzając, że jeśli tylko kobiety dostaną szansę wzięcia udziału w projektach edukacyjnych, w tym z zakresu biznesu społecznego, to Bangladesz doświadczy wzrostu i przyspieszonego rozwoju gospodarczego, przedsiębiorca trafnie zidentyfikował główną przyczynę zacofania rozwojowego kraju. Rolą biznesu społecznego jest zmniejszanie deficytów rozwojowych będących efektem braku poszanowania praw i wyeliminowania połowy populacji z rynku pracy.

\section{Bibliografia}

Cornwall A., Women empowerment: What works and why?, „World Institute for Development Economics Research" 4 (3), 2014, s. 1-30.

Debdatta P., Dutta O., Microcredit and empowerment of urban women: A Study from Eastern India, „Strat Change" 24 (2), 2015, s. 149-163.

Duflo E., Women empowerment and economic development, „Journal of Economic Literature” 50 (4), 2012, s. 1051-1079.

Esther M.M., Empowerment for grassroots women, „Development” 53 (2), 2010, s. 197-199.

Johnson P., Unmarried in Palestine: Embodiment and disempowerment in the lives of single Palestine women, „IDS Bulletin” 41 (2), 2010, s. 106-115.

Khattak S., Women in local government: The Pakistan experience, „IDS Bulletin” 41 (5), 2010, s. 52-61.

Lewin T., Communicating empowerment: Countering the cardboard women, „Development” 53 (2), 2010, s. 222-226.

Nazneen S., Tasneem S., A silver lining: Women in reserved seats in local government in Bangladesh, „IDS Bulletin" 41 (5), 2010, s. 35-42.

Sagot M., Does the political participation of women matter? Democratic representation, affirmative action and quotas in Costa Rica, „IDS Bulletin” 41 (5), 2010, s. 25-34.

Sardenberg C., What makes domestic violence legislation more effective?, „Pathways Policy Paper” październik 2011.

Sharma D., Sudarshan R., Towards a politics of collective empowerment: Learning from hill women in rural Uttarakhand, India, „IDS Bulletin” 41 (52), 2010, s. 43-51.

Sholkamy H., How can social protection provide social justice for women?, „Pathways Policy Paper” październik 2011.

Sholkamy H., Steady Money. State Support and Respect Can Equal Woman's Empowerment in Egypt, [w:] Feminisms, Empowerment and Development: Changing Women's Lives, red. A. Cornwall, J. Edwards, Zedd Books, London 2014.

Tadros M., Woman in Politics: Gender, Power and Development, Zed Books, London 2014.

Yunus M., Weber K., Building Social Business, Public Affairs, New York 2010.

\section{Źródła internetowe}

BRAC ranked top global NGO of 2018, http://www.brac.net/latest-news/item/1145-brac-ranked-top-global-ngo-of-2018 (dostęp: 1.05.2018). 
Chen Y., Microfinance program in BRAC - the largest NGO in the world, IEPM 3110, International Organizations and Economic Development, s. 11, https://static1.squarespace.com/static/56645cece4b0957c43a61e07/t/5696623ad8af10829fdfb431/1452696125594/3110+term+paper_final.pdf (dostęp: 1.05.2018).

Magura District Information, http://aboutbangladesh71.blogspot.com/2013/01/magura district-bangladesh. html (dostęp: 1.05.2018).

Yunus M., Social business, http://www.muhammadyunus.org/index.php/social-business/social-business (dostęp: 1.05.2018).

\section{The role of social business in the process of women's empowerment in Bangladesh on the example of BRAC organization's activities in Magura district}

Keywords: women's empowerment, social business, BRAC Bangladesh Rehabilitation Assistance Committee

Summary

Women's empowerment is a process of gradual growth of the spiritual, political, social and economic strength of individuals, communities or entire societies. Strengthening the social position often entails strengthening confidence in one's own abilities. It is also connected with full participation of women in economic life in all sectors, which is very important in the context of strengthening economies and achieving desirable goals of sustainable development. Social business introduces a completely revolutionary dimension to a free market economy. This does not interfere with the profit-generating mechanism, on the contrary, it promotes investment, management and competitiveness. Satisfaction obtained in achieving specific social goals is the only motive for the investment, and the resulting business is assessed in accordance with this standard. The article presents the process of empowering poor women from the rural district of Magura in Bangladesh, possible to carry out through the activities of the BRAC (Bangladesh Rehabilitation Assistance Committee). The work refers to the effectiveness of activities in the field of social business, first in the context of changing the awareness of rights and the self-worth of women taking part in such projects, and secondly in the context of improving their socio-economic status and exiting poverty. 